\title{
Adoption and Dis-Adoption of Sustainable Agriculture: A Case of Farmers' Innovations and Integrated Fruit Fly Management in Kenya
}

\author{
Charity M. Wangithi ${ }^{1}\left(\mathbb{D}\right.$, Beatrice W. Muriithi ${ }^{1, *(\mathbb{D})}$ and Raphael Belmin ${ }^{2,3}$ \\ 1 International Centre of Insect Physiology and Ecology (ICIPE), P.O. Box 30772-00100 Nairobi, Kenya; \\ wangithimuthoni@gmail.com \\ 2 Agricultural Research Centre for International Development (CIRAD), UPR HortSys, \\ F-34398 Montpellier, France; raphael.belmin@cirad.fr \\ 3 HortSys, University Montpellier, CIRAD, F-34398 Montpellier, France \\ * Correspondence: bmuriithi@icipe.org; Tel.: +254-(0)-20-863-2144; Fax: +254-(20)-8632001/2
}

\section{check for} updates

Citation: Wangithi, C.M.; Muriithi, B.W.; Belmin, R. Adoption and Dis-Adoption of Sustainable Agriculture: A Case of Farmers' Innovations and Integrated Fruit Fly Management in Kenya. Agriculture 2021, 11, 338. https://doi.org/ 10.3390/agriculture11040338

Academic Editor: Mohsin Tanveer, Mirza Hasanuzzaman and Ejaz Ahmad Khan

Received: 19 February 2021

Accepted: 5 April 2021

Published: 9 April 2021

Publisher's Note: MDPI stays neutral with regard to jurisdictional claims in published maps and institutional affiliations.

Copyright: (c) 2021 by the authors. Licensee MDPI, Basel, Switzerland. This article is an open access article distributed under the terms and conditions of the Creative Commons Attribution (CC BY) license (https:/ / creativecommons.org/licenses/by/ $4.0 /)$.

\begin{abstract}
The invasive fruit fly Bactrocera dorsalis poses a major threat to the production and trade of mango in sub-Saharan Africa. Farmers devise different innovations to manage the pest in an attempt to minimize yield loss and production costs while maximizing revenues. Using survey data obtained from Embu County, Kenya, we analyzed farmers' knowledge and perception as regards the invasive fruit fly, their innovations for the management of the pest, and the determinants of their adoption and dis-adoption decisions of recently developed and promoted integrated pest management (IPM) technologies for suppression of the pest. The results show that farmers consider fruit flies as a major threat to mango production (99\%) and primarily depend on pesticides (90\%) for the management of the pest. Some farmers (35\%) however use indigenous methods to manage the pest. Though farmers possess good knowledge of different IPM strategies, uptake is relatively low. The regression estimates show that continued use of IPM is positively associated with the gender and education of the household head, size of a mango orchard, knowledge on mango pests, training, contact with an extension officer, and use of at least one non-pesticide practice for fruit fly management, while IPM dis-adoption was negatively correlated with the size of the mango orchard, practice score and use of indigenous innovations for fruit fly management. We recommend enhancing farmer's knowledge through increased access to training programs and extension services for enhanced adoption of sustainable management practices for $B$. dorsalis.
\end{abstract}

Keywords: fruit flies; integrated pest management; farmers' innovations; mango; Kenya

\section{Introduction}

Mango fruits, Mangifera indica are valued across the tropics for both food and nutritional security, as well as employment and income generation. In Kenya, mango is the second most valuable fruit after bananas, accounting for 19.4\% of fruit exports in 2017 [1] Although in recent years the area under mango has increased, for instance by $3 \%$ between 2016 and 2017, productivity continued to decline [1,2]. The country's production is still far below the expected potential of about 2.8 million metric tons per year, with pests and diseases cited as the main challenge contributing to this gap, chief among them the Tephritid fruit fly Bactrocera dorsalis (Hendel). Other biotic causes for productivity loss include mango seed weevil pest, powdery mildew, and anthracnose diseases. B. dorsalis causes both direct and indirect mango losses (up to $80 \%$ according to Goergen et al. [3]). The reduction in mango productivity and quality results in smaller market value of the mango fruits and reduction in farmers' income [4,5]. Moreover, $B$. dorsalis is subject to a sanitary barrier to the trade of fresh fruit commodities, threatening access to the international market, and the food security of millions of mango farmers worldwide [6]. 
To keep the damages from $B$. dorsalis below the economic injury levels, mango farmers in Kenya often rely on synthetic pesticides [7], which not only increases the cost of production but also causes harmful effects to the environment and human health [8-10]. Moreover, the persistent use of insecticides may result in high insecticide residue levels, which reduce the marketability of the products especially in the global markets [11].

Both farmers and scientists, however, actively innovate to mitigate the invasive pest impact using alternative methods other than the harmful and expensive insecticides. Generally, farmers' innovations form an integral part of sustainable agriculture including the use of indigenous cropping and/or livestock systems [12]. Tambo and Wünscher [13] argue that innovations developed by farmers could supplement the highly promoted and externally driven technologies in addressing the numerous challenges facing agriculture. Like many farmers in developing countries, farmers in Kenya have their grass root innovations to manage the fruit fly pest. These innovations are majorly guided by either available local materials, for instance, the use of plant-based organic pesticides such as neem (Azadirachta indica), bitter herbs such as pepper (Capsicum spp.), tobacco (Nicotiana tabacum), and ash, or informed by the existing farming systems in a community [14,15]. Similarly, scientists have developed and disseminated integrated pest management (IPM) practices as an alternative to broad-spectrum insecticides for the suppression of invasive fruit flies. For close to a decade, the International Centre of Insect Physiology and Ecology (ICIPE) and development partners have developed and widely promoted the fruit fly IPM approach in the sub-Saharan African horticultural industry [16]. The approach comprises five components that target the pest from the eggs to the adult using a combination of biological, cultural, and physical pest control strategies. These include the use of the male annihilation technique (MAT), spot application of protein food bait, application of Metarhizium anisopliae-based biopesticides, the release of parasitoids, and orchard sanitation $[4,5,16,17]$. Adoption of fruit fly IPM has been found to generate significant economic, health, and environmental benefits among mango growers and consumers $[4,5,9,10,18,19]$.

Despite the demonstrated interest and benefits of fruit fly IPM, the adoption of the technologies by the Kenyan mango farmers is still low. While farmers should use at least three of the five IPM components to significantly suppress the fruit flies, a recent study by Midingoyi et al. [18] in Embu, Meru, and Machakos shows that only $12 \%$ of the sampled farmers had achieved this threshold, while a significant proportion of them $(29 \%)$ were not using any of the IPM methods, despite being aware of their existence and associated benefits. Farmers' choice between the use of pesticides, indigenous technical knowledge, and IPM is mainly driven by cost implication, expected financial gains from increased production, and protection of the ecosystem [8]. For fruit fly IPM, the adoption dynamics have not been fully understood. Similarly, to other sustainable agricultural technologies, a wide body of the literature focus on the binary analysis of adoption, that is, between adopters and non-adopters [20,21], with only a few focusing on factors affecting discontinuous (dis-adoption) of technologies (e.g., An [22], Hassen [23], Neill and Lee, [24], and Simtowe and Mausch [25]).

This study contributes to the existing literature in three ways. First, we analyze the existing farmer's inventions for the management of mango-infesting invasive fruit flies. We adopt on-farm tracking of farmers' innovations suggested by Salembier et al. [12] to identify alternative fruit fly management practices dominant in the mango production system in Kenya. This is the first study to our knowledge to study on-farm innovations for the management of invasive fruit flies. Second, we assess how farmers' knowledge and perceptions towards the invasive fruit flies and management practices including the use of IPM and other non-pesticides have changed over time since the initial dissemination and promotional efforts of the technologies. Third, we evaluate the determinants of adoption and dis-adoption decisions of the fruit fly IPM practices. The determinants of the latter group of IPM adoption have not been studied previously. To address these gaps, the study utilized primary data collected through face-to-face interviews with mango-growing 
households at the first site in Kenya and sub-Saharan Africa to receive the ICIPE's fruit fly IPM strategy over a decade ago.

\section{Material and Methods}

\subsection{Conceptual Framework and Empirical Approach}

Farmers' decisions to adopt, dis-adopt, or not adopt the fruit fly IPM practices can be modeled using the random utility theory $[23,25]$. Farmers are assumed to be economically rational and will only adopt a technology if the utility derived from using it is higher than the utility derived from not using it. Assuming the utility derived from using IPM practices is $U_{i p m}^{a}$ and utility derived from not adopting is $U_{i p m}^{n}$, then a farmer will only adopt it if

$$
Y_{i p m}^{*}=U_{i p m}^{a}-U_{i p m}^{n}>0
$$

and will not adopt it if

$$
Y_{i p m}^{*}=U_{i p m}^{n}-U_{i p m}^{a}>0
$$

where $Y_{i p m}^{*}$ is the latent benefits accruing from adopting or not adopting the IPM practices. The adoption/non-adoption decision is dichotomous and has been mainly modeled using Probit or logit regression models. Furthermore, if the utility derived from continued use (say utility $U_{i p m}^{d}$ ) of IPM diminishes, a farmer will abandon the use of IPM. Subsequently, the latent benefit from continued use of IPM can be defined as:

$$
Y_{i p m}^{*}=U_{i p m}^{a}-U_{i p m}^{d}>0
$$

The dis-adoption decision presents a third category of farmers' decisions that is often ignored when evaluating static adoption—adoption vs. non-adoption—decisions [26,27]. Treating early dis-adopters and non-adopters the same, as is often done in static models, may result in misleading and biased coefficient estimates as it ignores the dynamic effect of learning and the inability to control for unobserved heterogeneity [28]. To model the above decisions, therefore, we employ a multinomial logistic regression (MNL) to determine the determinants of farmer's decisions to adopt, dis-adopt, or not to adopt the fruit fly IPM practices. The MNL model allows institutional, socio-economic, and farming characteristics to have different effects on the relative probabilities between any two choices [29]. MNL is considered more attractive to Multinomial Probit due to its computational simplicity in calculating the choice probabilities that are expressible in analytical form and does not assume normality, linearity, or homoscedasticity [30]. The independence of the irrelevant alternatives (IIA) property is the main limitation of this model which states that the ratio of the probabilities of choosing any two alternatives is independent of the attributes of any other alternative in the choice set.

Let $A_{j}$ be a random variable representing the adoption decisions of mango farming households. It is assumed that each farmer faces a set of discrete, mutually exclusive choices of adoption which depend on individual's and farming characteristics and other contextual factors $X$ [31]. The specification on the relationship between the probability of choosing option $A_{j}$ and the set of explanatory variables $\boldsymbol{X}$ can be modeled as follows [31]:

$$
P_{j}\left(A_{j}=k\right)=\frac{\exp \left(\beta_{k} X_{j}\right)}{\sum_{l}^{k} \exp \left(\beta_{l} X_{j}\right)} k=0,1 \ldots, k
$$

To eliminate indeterminacy in the model, we assume that $\beta_{k}=0$, then the probability estimates $\left(P_{j}\right)$ are derived as:

$$
P_{j}\left(A_{j}=k \mid X_{k}\right)=\frac{\exp \left(\beta_{k} X_{j}\right)}{1+\sum_{l}^{k} \exp \left(\beta_{l} X_{j}\right)} \quad k=0,1 \ldots, k ; \beta_{0}=0
$$


Estimating Equation (5) yields the $k$ logs-odd ratios meaning that the outcome variable is the $\log$ of one alternative relative to the base.

$$
\ln \left(\frac{P_{j k}}{P_{j l}}\right)=X_{j}^{!}\left(\beta_{k}-\beta_{l}\right)=X_{k}^{!}, \text {if } l=0
$$

To interpret the effects of explanatory variables on the probabilities of a specific adoption choice being made for a unit change in the independent variable we estimate marginal effects as follows.

$$
\delta_{k}=\frac{\delta P_{k}}{\delta X_{j}}=P_{k}\left[\beta_{k}-\sum_{l=0}^{k} P_{l} \beta_{l}\right]=P_{k}\left(\beta_{k}-\bar{\beta}\right)
$$

where $X_{j}$ and $X_{k}$ are vectors of observable explanatory variables (including farmer and farm characteristics, and institutional and market access indicators) that may affect the three possible outcomes $\left(Y_{i p m}\right)$; that is, the probability that a farmer adopts the fruit fly IPM and continues to use it, the farmer adopts then dis-adopts the technology, or the farmer never adopts it. Considering that the ICIPE fruit fly IPM strategy was first disseminated in Kenya close to a decade ago, our study modeled adoption in two steps. First, we analyze factors influencing the current use of the IPM where we apply a discrete choice Probit model (1 if a household is currently using fruit fly IPM and zero otherwise). Despite the fact that the fruit fly IPM comprises five different components, as mentioned in the introduction section, the use of male annihilation technique (MAT), commonly referred to as Fruit fly traps, was used in this study as the proxy for fruit fly IPM adoption, as this is the most common and commercialized component of the IPM strategy. Orchard sanitation is equally popular, but not a commercial product since the activity only requires farm labor. Furthermore, Muriithi et al. [5] and Midingoyi et al. [18] demonstrate that the use of MAT alone can result in significant yield gains. The use of orchard sanitation alone on the other hand may not yield a significant impact as observed by Muriithi et al. [5]. The discrete choice Probit model can be expressed as follows

$$
P\left(Y=1 \mid X_{1} \ldots X_{k}\right)=\Phi\left(\beta_{0}+\beta_{1} X_{1}+\beta_{2} X_{2}+\ldots+\beta_{n} X_{n}\right)
$$

where $\Phi$ denotes the distribution function of the standard normal distribution, $X$ is a vector of observable explanatory variables that may influence the IPM adoption decisions, as outlined in Table 1 . The choice of explanatory variables $(X)$ is guided by the literature on the adoption of agricultural technologies [21,32,33], including IPM [34-38], and contextual characteristics. These studies observe that the adoption of agricultural technologies is dependent on several factors including personal, social, cultural, and economic characteristics, as well as those of the innovation itself. 
Table 1. Definition of Independent Variables Used in Probit and Multinomial Logit Regression Models.

\begin{tabular}{|c|c|c|c|}
\hline \multirow{2}{*}{ Explanatory Variables } & \multirow{2}{*}{ Variable Definition } & \multicolumn{2}{|c|}{ Expected Sign } \\
\hline & & Initial Adoption & Dis-Adoption \\
\hline \multicolumn{4}{|c|}{ Demographic variables } \\
\hline Gender household head & $1=$ male $0=$ Female & $-/+$ & $-/+$ \\
\hline Household size & Household size in count & $-/+$ & $-/+$ \\
\hline Education of household head & Number of schooling years of the household head & + & - \\
\hline Age of household head & Age of the household head & $-/+$ & $-/+$ \\
\hline \multicolumn{4}{|c|}{ Household resources } \\
\hline Mango experience & Number of years in mango farming & $-/+$ & $-/+$ \\
\hline Share of farm income & $\begin{array}{c}\text { Proportion of farm income out of total annual } \\
\text { household income }\end{array}$ & + & - \\
\hline Share of mango income & $\begin{array}{c}\text { Proportion of mango income out of total annual } \\
\text { household income }\end{array}$ & + & - \\
\hline Mango trees & Total number of mango trees in production & + & - \\
\hline Mango area & Area under mango in Acres & + & - \\
\hline Farming system & $\begin{array}{c}1=\text { Mixed crop and livestock } \\
0=\text { Crop only }\end{array}$ & + & - \\
\hline Farm size & Total owned land in Acres & + & - \\
\hline \multicolumn{4}{|c|}{ Access to market and institutional information } \\
\hline Training attendance & $\begin{array}{c}\text { Attended training on mango production and/or } \\
\text { marketing } \\
1=\text { yes, } 0=\text { No }\end{array}$ & + & - \\
\hline \multicolumn{4}{|c|}{ Distance in walking minutes } \\
\hline Access to output Market & Distance to nearest output market & - & + \\
\hline Access to input Market & Distance to the nearest source of input & - & + \\
\hline Access to extension services & Distance to nearest extension offices & - & + \\
\hline Access to credit sources & Distance to the nearest credit source & - & + \\
\hline Contact extension officer & $\begin{array}{l}\text { Visited by an extension officer in the last } 12 \text { months } \\
\qquad 1=\text { Yes, } 0=\text { No }\end{array}$ & + & - \\
\hline \multicolumn{4}{|c|}{ Social capital and networks } \\
\hline Membership of mango group & $\begin{array}{l}\text { Membership to a mango production/marketing group } \\
\qquad 1=\text { Yes, } 0=\mathrm{No}\end{array}$ & + & + \\
\hline Membership of rural institution & $\begin{array}{l}\text { Membership to any rural institution } \\
\qquad 1=\text { Yes, } 0 \text { = No }\end{array}$ & + & + \\
\hline \multicolumn{4}{|c|}{ Knowledge, and practices } \\
\hline Knowledge score & $\begin{array}{c}\text { Knowledge of non-pesticide fruit fly control strategies } \\
\text { expressed as a score }\end{array}$ & + & - \\
\hline Practices score & $\begin{array}{c}\text { Use of non-pesticide fruit fly control strategies } \\
\text { expressed as a score }\end{array}$ & + & - \\
\hline Indigenous Innovations & $\begin{array}{l}\text { Use Indigenous Innovations to manage fruit flies } \\
\qquad 1=\text { Yes, } 0=\text { No }\end{array}$ & $-/+$ & $-/+$ \\
\hline
\end{tabular}

Note: ${ }^{\text {a }}$ Knowledge and practice scores were generated by summing up positive responses to various statements on awareness and use of different non-pesticide practices for management of $B$. dorsalis. $-/+$ suggests that the expected sign is inconclusive.

\subsection{Study Area and Survey Data}

The data utilized in this study were obtained from a randomly selected sample of mango-growing households in Embu county, Kenya (Figure 1). The county is a good representation of the mango sub-sector in Kenya and sub-Saharan Africa as most regions grow the crop under similar climatic conditions and farming practices [39-41]. Moreover, the county ranks among the top mango-producing counties in Kenya [1]. The agriculture sector plays a significant economic role in the county. It comprises both cash crops (tea, coffee, cotton, fruit trees, macadamia nuts, and khat) and food crops (maize, beans, sorghum and millet, sweet potatoes) and livestock (cattle, shoats, poultry, and pigs). The sector contributes over $70 \%$ of the county's economic base, generates $26 \%$ of the foreign exchange earnings, and employs over $85 \%$ of the county's rural population. The biggest share of the agriculture sector contribution comes from the horticulture sub-sector. During the year 2015, the sub-sector earned the county USD 100 million from 164,000 MT of vegetables, USD 3.6 million from 180,000 MT of bananas, and USD 480,000 from 109,000 MT of mango. Mango is the main cash crop in the lower-middle altitude region of the county [42]. 
A two-stage sampling technique was adopted, where two sub-counties (Runyenjes and Manyatta) were purposively selected based on mango production predominance. A list of mango farmers from the two sub-counties was then developed with the help of sub-county and ward agricultural officers. The list provided a sampling frame from which a sample of 165 mango growing households was randomly selected. The survey took place in August 2019 covering the preceding mango cropping season. Data were collected by trained enumerators using a pre-tested structured questionnaire programmed in Cspro software. The survey captured detailed information on mango production including knowledge, perception, and practices towards mango-infesting pests and diseases, farm and farmer characteristics, proxies for social capital and networking variables, market access, and institutional information, and other contextual characteristics that influence the adoption of non-pesticides innovations such as IPM. To capture farmers' knowledge and perception of mango-infesting pests and diseases, a stack of photographs of the most common pests and diseases and their infestation symptoms was presented to the farmers for correct identification. Similarly, photos of different pest and disease management practices including fruit fly IPM components were presented to capture farmers' awareness and utilization of the different practices. To track farmers' innovations in the management of invasive fruit flies, the respondents were asked if they used any indigenous methods to manage the pest. They were asked to describe the methods, including where they first learned about them and the reasons for using them.

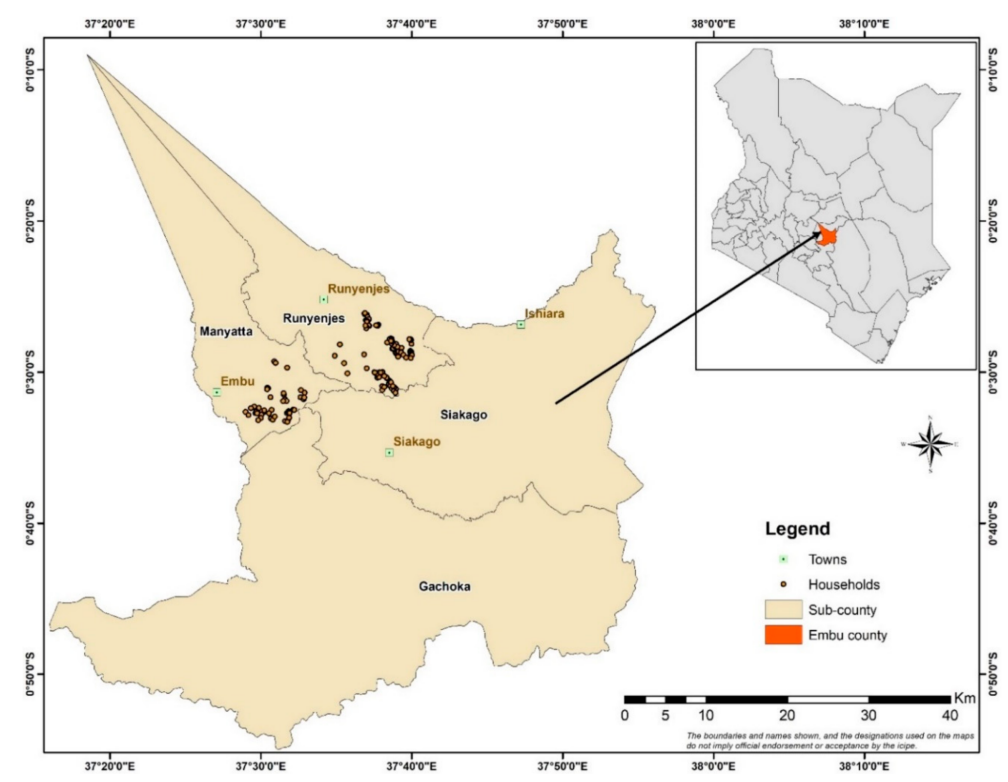

Figure 1. Map of the study area.

\section{Results}

\subsection{Descriptive Statistics}

\subsubsection{Dynamics of Fruit Fly IPM Adoption}

As highlighted earlier, we classified the sampled households into three groups based on their status of fruit fly IPM use. Those who were using fruit fly traps during the survey were categorized as fruit fly IPM adopters, those who had never used any of the fruit fly IPM components as non-adopters, while farmers who had previously used some components of the strategy but were not using them during the survey or were not planning to purchase for the succeeding season were classified as dis-adopters. Based on this classification, $53 \%$ were adopters, $26 \%$ were non-adopters, and the rest dis-adopters. Among those who had stopped using fruit fly traps, the majority cited unavailability of the product on the market (34\%), cost (31\%), and lack of price incentives for pesticide-free mango fruits $(14 \%)$ as the major reasons for the technology abandonment. Farmers who had stopped using the biopesticide and orchard sanitation using augmentation similarly 
cited unavailability of the products on the market. Although orchard sanitation is viewed as one of the most popular methods of managing fruit flies since it is not capital intensive, most respondents $(50 \%)$ had stopped practicing it citing that the IPM component required intensive labor (64\%). However, most (82\%) survey respondents perceived IPM to be more effective in the management of fruit flies compared to the use of synthetic pesticides $(75 \%)$ and acknowledged that the use of non-pesticide methods reduced the cost of production and increased income through higher sales and better-quality fruits.

\subsubsection{Knowledge and Perception of Mango-Infesting Fruit Flies and Their Management Practices}

All the sampled mango growers correctly identified the invasive fruit fly and associated it with significant loss of their mango crop, with $98.8 \%$ of them citing it as the major threat to mango production. The perceived mango losses due to fruit flies varied among the three categories of farmers (Figure 2). The IPM non-adopters perceived high severity of the pest of about $33 \%$ loss out of the total production while on average IPM adopters reported about $27 \%$ (Figure 2). On average, other mango-infesting pests and diseases were perceived to contribute about $9.3 \%$ and $8.6 \%$ of production loss, respectively (Figure 2). The survey respondents reported spending about Kenya Shillings (KES). 2850 (USD 28.5) on insecticides and KES.1400 (USD 14) on fungicides per acre per season.

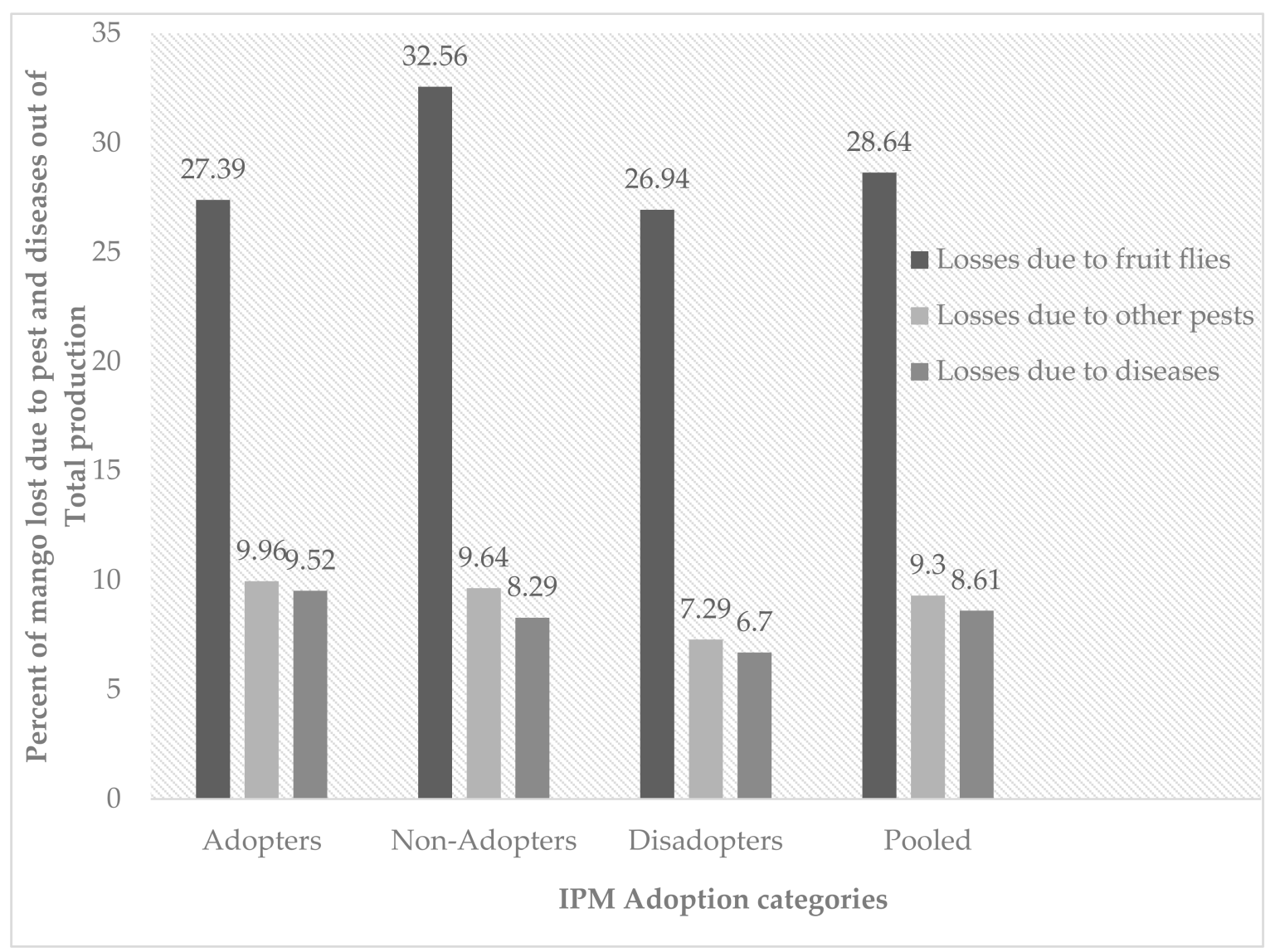

Figure 2. Perceived proportions of mango loss out of total production due to fruit flies and other mango-infesting pests and diseases in Embu County.

Figure 3 shows the survey respondent's knowledge and use of different mangoinfesting fruit flies management practices. The majority (90\%) of survey respondents used synthetic insecticides as the main method for the management of fruit flies. Although farmers possess good knowledge of different non-pesticide methods of management of fruit flies, the uptake is surprisingly low as demonstrated in Figure 3, possibly due to 
limited access to the products, cost, unstable produce market, and labor intensity for orchard sanitation, as highlighted in the previous section. Similar challenges have been observed by Parsa et al. [43] in their comprehensive overview of obstacles to IPM adoption in developing countries. Positive responses to various statements on awareness and use of different non-pesticide practices for management of $B$. dorsalis shown in Figure 3 were summed up to generate the knowledge and practice scores mentioned earlier in Table 1.

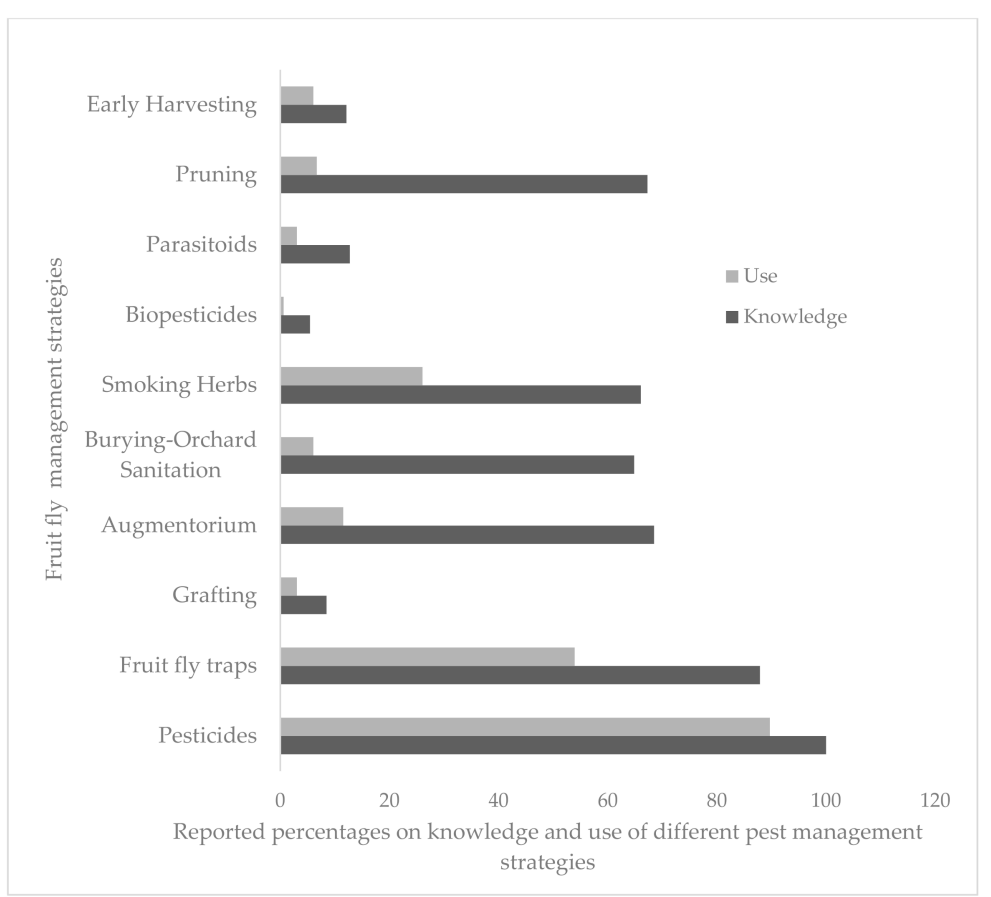

Figure 3. Knowledge and use of different fruit fly management practices in Embu County.

We also seek to uncover knowledge gaps in the application of the IPM practices. When asked their timing for setting up the fruit fly traps, most of the respondents reported that they laid traps at the fruit maturity stage $(36 \%)$ and ripening stage $(24 \%)$, while the rest laid their traps at the flowering stage (12\%), and when fruit flies attack the fruits $(1.2 \%)$. This finding demonstrates a knowledge gap as the recommended timing for setting up the fruit fly traps is from the onset of fruiting through to maturity and harvesting [44]. Furthermore, the trap lures (the attractant/insecticide mixture) should be replaced every 6-8 weeks for effective control of the male fruit flies [45]. Most of the interviewed mango growers however did not follow this recommendation with about $67 \%$ of them reporting that they did not replace the lures until the mango season was over, while a few, $21 \%$, and $12 \%$, repeated the exercise every 8 weeks and 4 weeks, respectively. The frequency of lure replacement however may vary depending on the type and longevity of the attractant, retention capacity of the lure, rate of fruit fly catch, the season of fruit fly activity, placement of the traps, the fruit fly species, and weather conditions [46]. For example, lures containing methyl eugenol attractant for control of $B$. dorsalis should be replaced after 7 weeks on average. Improper timing of setting up the traps and replacement of the lures may reduce the effectiveness of the MAT technology and therefore discourage continued use of the practice.

\subsubsection{Farm and Farmer Characteristics}

A descriptive summary of selected farm and farmer characteristics of the sampled households grouped by the IPM adoption status is provided in Table 2. A statistical F-test was conducted to test the difference in the means' variances of the three groups.

The results show that the majority of the IPM adopting households are headed by males $(88 \%)$ and that they dominated $(60 \%)$ in the management of their mango orchards, suggesting that men control the mango sub-sector. Fruit fly IPM adopters had relatively 
more years of education in comparison to non-adopters and dis-adopters. Other factors that were significantly different among the three groups include the proportion of mango income out of total annual household income, number of years in mango farming, acreage under mango, number of mango trees in production, farmers' contact with extension officers, mango group membership, knowledge and practices on IPM, and members training attendance as shown in Table 2. To attain knowledge and practice scores, farmers were presented with dichotomous questions ( $\mathrm{Yes} / \mathrm{No}$ ) on the different non-pesticide fruit fly management strategies (presented in Figure 3) and asked if they were aware of the practice (knowledge) and if they had ever used it (practice). The total number of correct answers was then summed up to represent the score.

Table 2. Comparison of farm and farmer characteristics of sample households across different fruit fly IPM adoption groups in Embu county, Kenya.

\begin{tabular}{|c|c|c|c|c|c|}
\hline \multirow[b]{2}{*}{ Explanatory Variables } & \multicolumn{4}{|c|}{ Mean/Percentiles } & \multirow[b]{2}{*}{ F-Test } \\
\hline & $\begin{array}{l}\text { Pooled } \\
n=165\end{array}$ & $\begin{array}{c}\text { Adopters } \\
n=87\end{array}$ & $\begin{array}{l}\text { Non-Adopters } \\
\quad n=43\end{array}$ & $\begin{array}{l}\text { Dis-Adopters } \\
\quad n=35\end{array}$ & \\
\hline \multicolumn{6}{|l|}{ Demographic characteristics } \\
\hline \multicolumn{6}{|l|}{ Gender of the household head } \\
\hline Male & 80 & 87.36 & 69.77 & 74.29 & \\
\hline Female & 20 & 12.64 & 30.23 & 25.71 & $3.31 \times$ \\
\hline Household size (count) & 3.65 & 3.67 & 3.60 & 3.57 & 0.05 \\
\hline Education of the household head (years) & 9.52 & 10.26 & 8.67 & 8.58 & $4.67^{* * *}$ \\
\hline Age of the household head (years) & 59.21 & 59.75 & 57.04 & 60.54 & 0.91 \\
\hline \multicolumn{6}{|l|}{ Household resources } \\
\hline Mango experience (years) & 15.50 & 16.91 & 12.84 & 15.26 & $4.26^{* *}$ \\
\hline Share of farm income $(\%)$ & 53.75 & 69.28 & 59.77 & 65.63 & 1.78 \\
\hline Share of mango income $(\%)$ & 28.54 & 33.13 & 21.91 & 24.74 & $5.97^{* * *}$ \\
\hline Mango area (Acres) & 1.2 & 1.56 & 0.81 & 0.81 & $5.3^{* * *}$ \\
\hline Mango trees in production & 92 & 124 & 42 & 76 & $5.39 * * *$ \\
\hline Farming system (crop-livestock) & 96.36 & 95.40 & 95.35 & 100.00 & 0.83 \\
\hline Farm size (Acres) & 4.21 & 5.13 & 2.98 & 3.46 & 1.89 \\
\hline \multicolumn{6}{|c|}{ Access to market and institutional information } \\
\hline Training Attendance; YES & 47.88 & 67.82 & 25.58 & 25.71 & $17.5^{* * *}$ \\
\hline $\begin{array}{l}\text { Access to output market (distance in } \\
\text { walking minutes) }\end{array}$ & 53.75 & 54.39 & 44.88 & 63.09 & 1.49 \\
\hline $\begin{array}{l}\text { Access to input market (distance in } \\
\text { walking minutes) }\end{array}$ & 34.88 & 33.13 & 31.51 & 43.37 & 2.21 \\
\hline $\begin{array}{l}\text { Access to agricultural extension services } \\
\text { (distance in walking minutes) }\end{array}$ & 82.81 & 79.89 & 84.65 & 84.57 & 0.15 \\
\hline $\begin{array}{l}\text { Access to credit source (distance in } \\
\text { walking minutes) }\end{array}$ & 82.81 & 79.1 & 83.63 & 91 & 0.45 \\
\hline Contact with extension officer: YES & 46.08 & 60.92 & 30.23 & 28.57 & $8.93^{* * *}$ \\
\hline \multicolumn{6}{|l|}{ Social capital and networks } \\
\hline Membership mango group: YES & 12.73 & 21.84 & 2.33 & 2.86 & $7.37^{* * *}$ \\
\hline Membership rural institution: YES & 91.52 & 95.40 & 86.05 & 88.57 & 1.88 \\
\hline \multicolumn{6}{|l|}{ Knowledge and practices ${ }^{a}$} \\
\hline Knowledge score & 26.57 & 30.39 & 20.58 & 23.57 & $10.37^{* * *}$ \\
\hline Practices score & 19.21 & 23.29 & 14.25 & 14.89 & $22.54^{* * *}$ \\
\hline Use Indigenous innovations: YES & 34.55 & 36.78 & 44.19 & 17.14 & $3.40 * *$ \\
\hline
\end{tabular}

Note: ${ }^{* *} p<0.05 ;{ }^{* * *} p<0.01 .{ }^{\text {a }}$ Knowledge and practice scores were generated by summing up positive responses to various statements on awareness and use of different non-pesticide practices for management of B. dorsalis as shown in Figure 3 . 
3.1.4. Farmers' Innovations for the Management of Tephritid Fruit Flies, Motivation, and Source of Information

Figure 4 shows the various indigenous methods innovated for the management of $B$. dorsalis. Among the most practiced method was smoking the flies using bitter herbs such as Mexican marigold (Tagetes erecta), tree marigold/ Mexican sunflower (Tithonia diversifolia), pepper, and aloe vera as reported by $56 \%$ of the sampled mango growers. Modification of existing strategies was also evident where farmers formulated food bait spray using molasses (as a bait) mixed with a pesticide (killing agent) (3.5\%) and the use of plant-based pesticides (neem and pyrethrum) $(1.8 \%)$. While the use of neem powder is highlighted in the previous studies as an effective practice for the management of the pest [47] there is no empirical evidence of the effectiveness of other reported methods such as smoking the trees, although the method has been mentioned as one of the native methods (farmer invention) for management of fruit flies $[48,49]$. Similarly, there is no scientific evidence on the effectiveness of the other farmer's self-reported practices. Rather than purchasing a complete pack of fruit fly traps (trap and lure), some farmers used old containers as traps and only bought the lures. By doing this, they saved about $40 \%$ of the cost per pack of the trap. On average, the cost of bactrolure (the mixture of an attractant and killing agent) alone cost about KES. 205 (USD 20.5) while a complete pack of the trap (bactrolure and a trap) costs on average KES. 345 (USD 34.5)).

\section{FARMER'S INNOVATIONS}

Smoking Green bitter herbs such as Mexican marigold, Tithonia diversifolia, pepper $\mathbf{5 6 . 1 4} \%$ Smoking using dry leaves and cow dung with combination of orchard sanitation $\mathbf{1 9 . 3 0} \%$ Food bait using molasses and a pesticide $\mathbf{3 . 5 1 \%}$

Plant based pesticides such as neem, pyrethrum $1.75 \%$

Combination of different conventional methods e.g., pruning $19.30 \%$

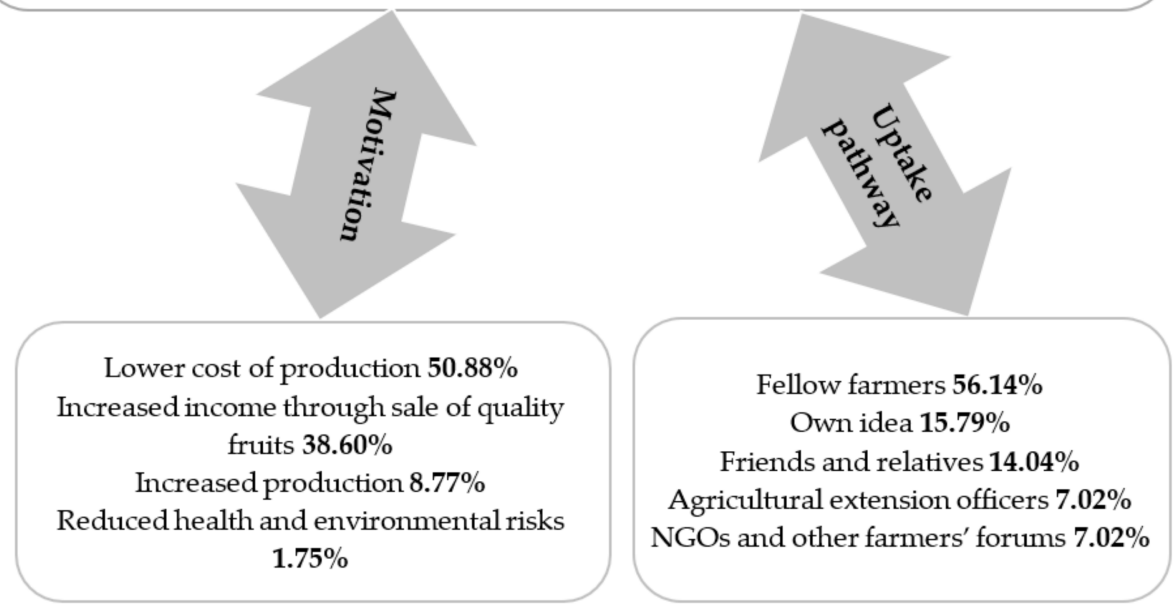

Figure 4. Farmers' innovations for the management of the mango fruit flies.

As noted by Tambo and Wünscher [13], farmers add value to existing practices or externally introduced techniques to solve their production constraints, save costs, and adapt to changing conditions. The innovations identified from our study are not exclusively new, but modifications of existing practices mainly aimed at fitting into the dominant traditional farming practices. Tambo and Wünscher [13] further noted that farmers' innovations are related to diverse farming practices and largely involve the use of local resources which are however not verified, but they increasingly spread through farmer networks. The major motivation for using the above innovations was reported to be reduced cost of production $(50.9 \%)$ and increased income through the sale of pesticide-free fruits (38.6\%). By mitigating against yield loss, farmers were able to have more output at a lower cost of production and have an assured market for their pesticide-free fruits. The major learning pathway of the innovations was through fellow farmers $(56.1 \%)$, suggesting the importance of social 
capital and networks in technology adoption. About $40 \%$ of the respondents were aware of other farmers who were also using similar indigenous methods to manage the mango fruit flies.

\subsection{Empirical Results}

\subsubsection{Determinants of Fruit Fly IPM Adoption}

The difference in knowledge and use of the fruit fly IPM strategies indicates anemic adoption rates among the smallholder mango growers with instances of dis-adoption. This study assessed the factors that influence farmers' decisions to adopt fruit fly IPM using the commercialized component (Male Annihilation Technique) as a proxy for IPM adoption. We begin by modeling the dichotomous IPM adoption decisions (IPM use or not) using the Probit model to test the hypothesis on characteristics associated with the farm and farmer and the study context on fruit fly IPM adoption. In this analysis, we combine dis-adopters and non-adopters and compare them with adopters (Table 3).

Table 3. Marginal effect of factors influencing the adoption of fruit fly integrated pest management (IPM); Probit estimates.

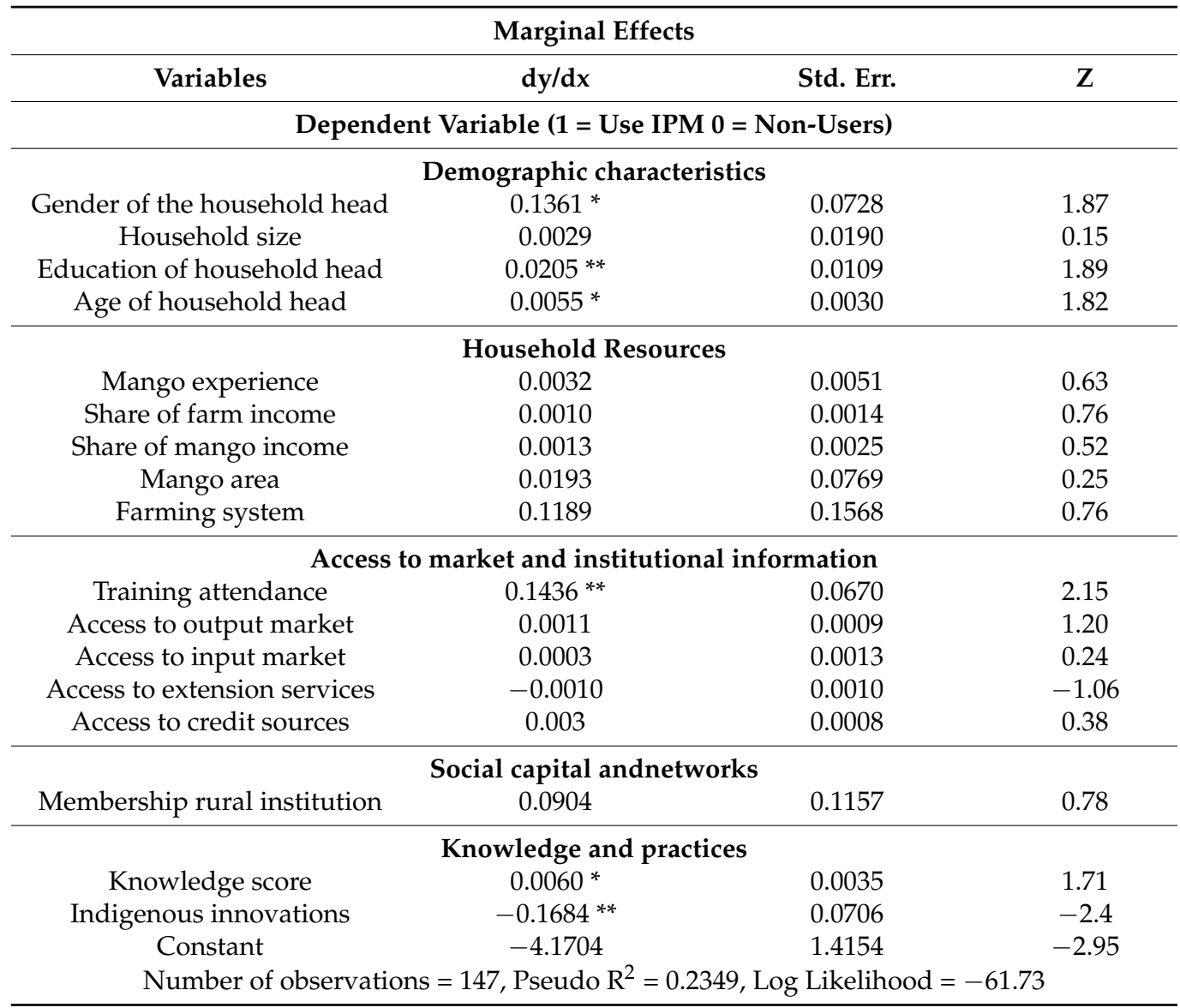

Note: Statistical significance at ${ }^{*} p<0.1 ;{ }^{* *} p<0.05$. dy $/ \mathrm{dx}$ (marginal effects) is the change in dependent variable (outcome) with respect to change in an independent variable (explanatory variables) changes, holding other variables constant.

With respect to demographic characteristics, the gender, age, and education of the household head increase the probability of fruit fly IPM adoption. For the proxies for access to market and institutional information and the social capital, training on mango production and/or marketing was positive and significantly related to fruit fly IPM adoption. Training either through extension officers or lead farmers has a desirable impact on the transfer of knowledge on improved technologies such as IPM. 
Among the knowledge and practices variables, the use of indigenous innovations was negative and significantly related to fruit fly IPM adoption while knowledge of different non-pesticide management strategies has a reverse effect on IPM adoption. This suggests that, even though knowledge on different strategies would encourage the adoption of IPM, the use of own farmers' innovations could be an obstacle to the use of IPM.

\subsubsection{Adoption, and Dis-Adoption of the Fruit Fly IPM Practices}

In most adoption studies, technology dis-adopters are ignored, often classified as non-users as we have done in the previous section. However, factors that may influence a farmer to attrite from technology adoption may not be the same as those causing others not to try the technology. Analyzing the two separately, therefore, may reveal important policy recommendations for sustainable adoption of the technology. We estimate a multinomial logistic regression model to identify the characteristics associated with IPM adoption, dis-adoption, and non-adoption. The regression results are presented in Table 4. The first two columns show the marginal effects for the continued IPM adopters, the next columns the non-adopters, and the last columns the dis-adopters.

Table 4. Drivers of adoption and dis-adoption of fruit fly IPM strategy in Embu County.

\begin{tabular}{|c|c|c|c|c|c|c|}
\hline \multicolumn{7}{|c|}{ Marginal Effects dy/dx } \\
\hline \multirow{2}{*}{ Variables } & \multicolumn{2}{|c|}{ Adopters } & \multicolumn{2}{|c|}{ Non-Adopters } & \multicolumn{2}{|c|}{ Dis-Adopters } \\
\hline & Coef. & Std. Err. & Coef & Std. Err & Coef & Std. Err \\
\hline \multicolumn{7}{|c|}{ Demographic characteristics } \\
\hline Gender household head & $0.2114^{* * *}$ & 0.0781 & -0.1041 & 0.0729 & -0.1073 & 0.0736 \\
\hline Household size & -0.0113 & 0.0193 & 0.0071 & 0.0185 & 0.0042 & 0.0204 \\
\hline Education of household head & $0.0253^{* * *}$ & 0.0095 & $-0.0222 * *$ & 0.0101 & -0.0032 & 0.0099 \\
\hline Age of household head & 0.0003 & 0.0030 & -0.0041 & 0.0029 & -0.0038 & 0.0034 \\
\hline \multicolumn{7}{|c|}{ Household resources } \\
\hline Mango experience & 0.0015 & 0.0046 & -0.0042 & 0.0049 & 0.0027 & 0.0046 \\
\hline Share of farm income & -0.0009 & 0.0012 & -0.0004 & 0.0013 & 0.0013 & 0.0011 \\
\hline Mango trees & 0.0004 & 0.0005 & -0.0007 & 0.0006 & -0.0002 & 0.0004 \\
\hline Mango area & $0.2343^{* * *}$ & 0.0806 & -0.0295 & 0.0766 & $-0.2048^{* * *}$ & 0.0810 \\
\hline \multicolumn{7}{|c|}{ Access to market and institutional information } \\
\hline Training attendance & $0.1152 *$ & 0.0698 & -0.0383 & 0.0832 & -0.0769 & 0.0783 \\
\hline Access to output market & 0.0003 & 0.0008 & -0.0010 & 0.0008 & 0.0007 & 0.0008 \\
\hline Access to extension services & -0.0004 & 0.0009 & 0.0012 & 0.0010 & -0.0009 & -0.0010 \\
\hline Access to credit source & -0.0001 & 0.0008 & -0.0004 & 0.0009 & 0.0004 & 0.0009 \\
\hline Contact Extension Officer & $0.1306 *$ & 0.0721 & -0.0415 & 0.0807 & -0.0891 & 0.0721 \\
\hline \multicolumn{7}{|c|}{ Social Capital and networks } \\
\hline Membership of rural institution & 0.1746 & 0.1229 & -0.1050 & 0.1115 & -0.0696 & 0.1141 \\
\hline Membership of mango group & 0.0993 & 0.1156 & -0.0282 & 0.1528 & -0.0711 & 0.1594 \\
\hline \multicolumn{7}{|c|}{ Knowledge and practices } \\
\hline Knowledge score & $0.0105^{* * *}$ & 0.0041 & 0.0026 & 0.0043 & $0.0079 * *$ & 0.004 \\
\hline Practices score & $0.0298^{* * *}$ & 0.0051 & $-0.0149^{* * *}$ & 0.0057 & $-0.0150^{* * *}$ & 0.0050 \\
\hline Indigenous Innovations & -0.0506 & 0.0734 & $0.1870^{* * *}$ & 0.0738 & $-0.1364 *$ & 0.0785 \\
\hline Constant & - & - & $9.1753 * * *$ & 2.73 & 4.7797 & 1.53 \\
\hline
\end{tabular}

Note: Number of observations $=145$, Pseudo $R^{2}=0.3827, \log$ Likelihood $=-88.79$. Note: ${ }^{* * *},{ }^{* *},{ }^{*}$ represent significance levels at $1 \%, 5 \%$ and $10 \%$, respectively.

Consistent with the Probit analysis in the previous section, the gender and education of the heads of households were positively associated with the continuous adoption of fruit fly IPM. With respect to household resources, the continued adoption of fruit fly IPM is positively associated with the size of a mango orchard, and the reverse is true for dis-adopters. This suggests that farmers who had allocated more land to mango were more likely to be adopters than dis-adopters. 
Knowledge and practices on mango pests and non-pesticide management strategies for the mango fruit fly are also positively associated with the continuous adoption of IPM. This is plausible as a farmer who is aware of different pests that affect his mango orchards and associated losses is likely to adopt a technology to reduce these losses. However, even though practices on non-pesticide management strategies were negatively related to the dis-adoption and non-adoption of IPM, knowledge score increased the probability of IPM dis-adoption. This suggests that even though farmers are aware of other management practices, knowledge alone does not adequately guarantee sustainable adoption of such agricultural technologies. The use of own indigenous innovations is positively related to non-adoption but negatively related to dis-adoption. This suggests that farmers who had their innovation to manage $B$. dorsalis were unlikely to adopt the use of IPM; however, those that successfully integrate IPM into their innovations, are unlikely to attrite. Subsequently, IPM and farmers' innovations are complementarities in the management of invasive mango fruit flies.

Training on mango farming and contact with an extension officer were also found to have a positive and significant influence on IPM adoption decisions. Farmers who had received training or had contact with an extension officer in the last two years were characterized by the continued adoption of IPM. Sensitization of farmers on mango production (i.e., pest management, inputs use, soil and water conservation) and marketing and value addition are the different forms of training farmers reported having been exposed to.

\section{Discussion}

\subsection{Determinants of Fruit Fly IPM Adoption}

The empirical analysis presented in the previous section showed that among demographic characteristics, gender, education, and age positively influence the adoption of IPM. Gender can influence on-farm decision-making due to resource availability and allocation. Though women are more aware of the potentially harmful effects of synthetic pesticides, the pest management decision is mainly made by the household head irrespective of their gender as argued by Erbaugh et al. [50]. However, men dominate as the household heads and plot managers in our study, and therefore a male-headed household is more likely to adopt IPM than a female-headed household. Furthermore, gender-linked differences in access to resources and inputs [51] for IPM Strategies could result in low adoption among female-headed households.

More years of education are often associated with more ability to acquire, comprehend, and interpret information relating to sustainable pest management. In addition, education is often viewed as human capital that facilitates access and interpretation of new information to address production constraints $[7,49,52]$. More educated farmers are likely to be aware of the harmful implications of using synthetic pesticides and therefore the effort to use more sustainable practices such as fruit fly IPM. Regarding age, more elderly farmers are likely to adopt IPM than their younger counterparts, and this is consistent with Rivera and Qamar's [53] suggestion that older household heads have greater chances of adopting new technologies. A conceivable explanation is that older farmers have more experience in pest management and therefore more aware of the benefits of IPM. Furthermore, older households may possess the resources required to invest in sustainable pest management practices. Age can also be interpreted as experience in farming which improves farmers ${ }^{\prime}$ skills in production and low level of uncertainty regarding innovations performance and can assess the advantages of new technology.

Though knowledge on non-pesticide management practices has a positive and significant relationship with the adoption of IPM, the use of indigenous innovation has the reverse effect. While farmers have mainly been described as adopters of technology rather than generators of technology [38,54], their innovations guide research and development of most technologies if verified and validated scientifically [55]. However, if farmers applaud the efficiency of their innovations parallel to other pest management methods, they are un- 
likely to adopt it [54]. Nevertheless, with more knowledge about non-pesticide strategies, the willingness to adopt IPM would increase significantly.

Training plays a key role in the adoption of IPM as revealed in our study. Our results are consistent with those of Balasha [35] and Muriithi et al. [56] who found agricultural training to be positively related to the potential adoption of IPM. Insufficient training and technical support to farmers have been cited by Parsa et al. [43] as the major obstacle to IPM adoption in developing countries. Although the importance of social networks in the adoption of agricultural technologies is overemphasized in the previous studies, e.g., [32,51,56,57], none of our social capital variables are significant, although it displayed a positive relationship with continued IPM adoption. However, given our small sample size, we cannot rule out the possibility that the data do not have adequate power to detect the true effect of rural group membership on IPM adoption. Through training, farmers receive extension services which play a major role in enhancing farmers' access to information on pest management strategies, use of inputs as well as market linkages [57-60]. Overall, our findings are consistent with Prokopy et al. [33] in their extensive literature review on the adoption of best agricultural management practices.

\subsection{Adoption, and Dis-Adoption of the Fruit Fly IPM Practices}

Continuous adoption of IPM practices was positively associated with gender and education of the household head. Education is viewed as human capital in knowledge and information interpretation which can enhance adoption decisions with a male household head is correlated with adoption of IPM in mango production as also revealed by Zwane [59]. As expected, more years of education were negatively related to the nonadoption of mango fruit fly IPM.

Disadoption was negatively associated with the size of the mango orchard while continued adoption was characterized by larger sizes of mango orchards. The results are consistent with other farmers' adoption behavior where land allocated to a specific crop is likely to have a positive influence on their decisions [61], probably to maximize returns from their larger farm sizes [56]. Furthermore, a farmer with more acreage under mango has commercialized his enterprise and therefore has the incentive to continue using the fruit fly IPM to reduce the economic losses associated with the pest. Moreover, they could be better resource endowered compared to the non-adopters, to facilitate investment in IPM practices, unlike the dis-adopters who mainly depended on the project's support.

While it is plausible to note that most of the farmers learned about the fruit fly IPM through the African fruit fly program of ICIPE, continued sensitization after the end of the project may have lacked from the local government institutions and crop protection extension service providers. This is shown by the empirical results where both knowledge and practices on non-pesticide management practices were positively associated with continuous adoption but the knowledge was positively linked to dis-adoption. This shows the need for continuous sensitization by the relevant institutions to ensure sustainable adoption of agricultural best practices. Lack of favorable government policies and support has been highlighted by Parsa et al. [43] as the most second important obstacle to IPM adoption in developing countries.

Farmers' innovation if integrated with IPM discourages disadoption; this shows IPM and farmers' innovation are complementary and emphasizes the need to borrow from the dominant farming systems while designing innovative sustainable farming practices. Training maintained a positive association with continuous adoption as in the Probit analysis. Farmers advance their knowledge and skills through training and these findings are consistent with other studies emphasizing the role of information in the adoption of IPM $[18,34,35,62]$. The positive association between contact with extension workers and continuous adoption is plausible as extension services enhance access and sharing of new knowledge and skills in the management of constraints such as invasive fruit flies. This is consistent with previous studies on the role of extension services in the adoption of agricultural technologies, e.g., [18,35,63-65]. 


\section{Conclusions and Policy Implications}

This study documented farmers' innovations for the management of mango-infesting fruit flies, assessed farmers' knowledge and perceptions towards fruit fly infestation, and use of fruit fly IPM, and evaluated the determinants of adoption and dis-adoption of the existing fruit fly IPM practices. The results reveal the use of synthetic pesticides as the major fruit fly management practice, despite the assiduous IPM promotion effort by ICIPE and partners in the study region. While the results demonstrate good knowledge of the fruit fly IPM and other non-pesticide fruit fly control practices, the uptake is very slow, presenting rather a disturbing epilogue on the adoption of sustainable agriculture such as IPM.

With regard to IPM adoption, we classified the farmers into three categories: adopters (those who were using at least one of the commercialized fruit fly IPM practice- fruit fly traps), dis-adopters (those who had previously used any of the IPM practice but stopped), and non-adopters (farmers that had never adopted any of these practices). The dis-adopters cited unavailability of the IPM products on the market, cost of the products, and lack of price incentives for their produce as the main reasons they stopped using the products.

Farmers are innovative in solving farm-level challenges such as the management of the invasive fruit fly pest. The use of smoke from bitter herbs such as Mexican marigold and pepper was among the main indigenous practices reported by the survey respondents for the management of tephritid fruit flies. These innovations are mainly based on the availability of local resources with the major motivation for adoption being to lower the cost of production and are mainly acquired from fellow farmers or other forms of social networks. Modification of the fruit fly traps was also evidenced, suggesting that farmers can pay less for the IPM products by adapting the locally available materials. The use of such indigenous innovations however requires scientific assessment and validation to understand their potential contribution to the sustainable management of the invasive mango-infesting fruit flies. Understanding the dominant farming practices such as indigenous innovation and blending them with new technologies such as IPM could enhance the adoption rates.

The empirical results showed a positive relationship between IPM adoption and gender, age and education level of the household head, training attendance, and knowledge on non-pesticide management. On the other hand, households with smaller mango orchards (in terms of land size) were likely to abandon fruit fly IPM technology. The dis-adopters seem to be well acquainted with the non-pesticide practices for the management of fruit flies as demonstrated by positive knowledge score; however, those that used such practices, as well as indigenous innovations, were less likely to stop using the IPM practices. To reduce the likelihood of farmers abandoning IPM and other agricultural technologies, continuous technical support by the relevant authorities such as government extension officers is key even after the end of the projects.

For successful design, dissemination, adoption, and diffusion of sustainable agricultural technologies such as IPM, both market, and household level characteristics play a role. Providing knowledge alone cannot sustain adoption, having access to the products is vital for continued use, as well as providing market incentives for pesticide-free produce. As demonstrated using the regression analysis, providing access to extension services could discourage the dis-adoption of the fruit fly IPM. In addition, continuous sensitization of farmers on different pest management strategies and positive externalities of using non-pesticides practices for pest control through farmers' training could also enhance the continued use of good agricultural best practices including IPM. While we find potential complementarities between IPM and farmers' innovations, further research is required to verify the effectiveness of the suggested indigenous inventions for the management of mango fruit flies. 
Author Contributions: B.W.M. and R.B. conceptualized the study and wrote the project proposal. B.W.M. and C.M.W. designed and conducted the household survey and analyzed the data. C.M.W., B.W.M. and R.B. contributed to writing the manuscript. All authors have read and agreed to the published version of the manuscript.

Funding: This research work was funded under the Europe-Africa Agricultural Research and Innovation Cooperation Program (LEAP-Agri) and the National Research Fund (NRF), Kenya through the International Centre of Insect Physiology and Ecology (ICIPE). ICIPE also receives core funding from the UK's Foreign, Commonwealth \& Development Office (FCDO), the Swedish International Development Cooperation Agency (Sida), the Swiss Agency for Development and Cooperation (SDC), the Federal Democratic Republic of Ethiopia, and the Kenyan Government. The views and opinions expressed here are those of the authors and do not necessarily reflect those of ICIPE or the donors.

Institutional Review Board Statement: Ethical review and approval were waived for this study, due to the long-standing working of the African Fruit Fly Programme (AFFP) in the study site. However, oral consent was sort from the respondents who were provided with sufficient information about the research to allow them to make informed and free decisions on their participation in the study.

Informed Consent Statement: Informed consent was obtained from all subjects involved in the study.

Data Availability Statement: The data presented in this study are available on request from the corresponding author.

Acknowledgments: The authors are thankful to the African Fruit Fly Programme (AFFP) of ICIPE for supporting field logistics, Sub-county and Ward agricultural officers who helped in obtaining a sampling frame, farmers who voluntarily participated in the household surveys, and the enumerators for their effort in data collection. We are also highly indebted to Menale, head of Social Science and Impact Assessment Unit of ICIPE for advice and support.

Conflicts of Interest: The authors declare that they have no conflict of interest.

\section{References}

1. Horticultural Crops Directorate (HCD). Horticulture Annual Validated Report for 2015-2016; Agriculture and Food Authority (AFA), Government of Kenya: Nairobi, Kenya, 2016. Available online: http://kilimodata.developlocal.org/dataset/horticulturevalidated-report-2016-2017/ resource/c7758a80-9102-481e-a6c2-fa983081221d (accessed on 19 January 2020).

2. Horticultural Crops Directorate (HCD). Horticulture Annual Validated Report for 2016-2017; Agriculture and Food Authority (AFA), Government of Kenya: Nairobi, Kenya, 2017. Available online: http://horticulture.agricultureauthority.go.ke/index.php/ statistics / reports (accessed on 20 February 2020).

3. Goergen, G.; Vayssières, J.-F.; Gnanvossou, D.; Tindo, M. Bactrocera invadens (Diptera: Tephritidae), a new invasive fruit fly pest for the Afrotropical region: Host plant range and distribution in West and Central Africa. Environ. Entomol. 2011, 40, 844-854. [CrossRef]

4. Kibira, M.; Affognon, H.; Njehia, B.; Muriithi, B.; Ekesi, S. Economic Evaluation of Integrated Management of Fruit Fly in Mango Production in Embu County, Kenya. Afr. J. Agric. Resour. Manag. 2015, 10, 343-353.

5. Muriithi, B.W.; Affognon, H.D.; Diiro, G.M.; Kingori, S.W.; Tanga, C.M.; Nderitu, P.W.; Mohamed, S.A.; Ekesi, S. Impact assessment of Integrated Pest Management (IPM) strategy for suppression of mango-infesting fruit flies in Kenya. Crop Prot. 2016, 81, 20-29. [CrossRef]

6. Badii, K.; Billah, M.; Afreh-Nuamah, K.; Obeng-Ofori, D.; Nyarko, G. Review of the pest status, economic impact, and management of fruit-infesting flies (Diptera: Tephritidae) in Africa. Afr. J. Agric. Res. 2015, 10, 1488-1498. [CrossRef]

7. Korir, J.K.; Affognon, H.D.; Ritho, C.N.; Kingori, W.S.; Irungu, P.; Mohamed, S.A.; Ekesi, S. Grower adoption of an integrated pest management package for management of mango-infesting fruit flies (Diptera: Tephritidae) in Embu, Kenya. Int. J. Trop. Insect Sci. 2015, 35, 80-89. [CrossRef]

8. Daku, L.S. Assessing Farm-Level and Aggregate Economic Impacts of Olive Integrated Pest Management Programs in Albania: An ex-ante Analysis. Ph.D. Thesis, Virginia Tech. Institute and State University, Blacksburg, VA, USA, 2002.

9. Macharia, I.N.; Mithöfer, M.; Waibel, H. Potential environmental impacts of pesticides use in the vegetable sub-sector in Kenya. Afr. J. Hortic. Sci. 2009, 2, 138-151.

10. Mwungu, C.M.; Muriithi, B.; Ngeno, V.; Affognon, H.; Githiomi, C.; Diiro, G.; Ekesi, S. Health and environmental effects of adopting an integrated fruit fly management strategy among mango farmers in Kenya. Afr. J. Agric. Resour. Econ. Vol. 2020, 15, 14-26.

11. Lux, S.; Ekesi, S.; Dimbi, S.; Mohamed, S.; Billah, M. Mango-Infesting Fruit Flies in Africa: Perspectives and Limitations of Biological. In Biological Control in IPM Systems in Africa; CABI Publishing: Wallingford, UK, 2003; Volume 277. 
12. Salembier, C.; Elverdin, J.H.; Meynard, J.-M. Tracking on-farm innovations to unearth alternatives to the dominant soybean-based system in the Argentinean Pampa. Agron. Sustain. Dev. 2016, 36, 1. [CrossRef]

13. Tambo, J.A.; Wünscher, T. Identification, and prioritization of farmers' innovations in northern Ghana. Renew. Agric. Food Syst. 2015, 30, 537-549. [CrossRef]

14. Dekker, L.; Messing, R.; No, H.B. Pest Management Guidelines. HITAR Brief No. 114. 2019. Available online: http://www. extento.hawaii.edu/kbase/reports/fruit_pest.htm (accessed on 19 July 2020).

15. Mallick, J.E. Effect of Indigenous Products and Bio Nutrients With Reduced Levels of Fertilizers of the Incidence of Insect Pests of Brinjal. Ph.D. Thesis, Orissa University of Agriculture and Technology, Bhubaneswar, India, 2013. Available online: https:/ / krishikosh.egranth.ac.in/handle/1/5810084060 (accessed on 29 July 2020).

16. Ekesi, S.; Mohamed, S.A.; De Meyer, M. Fruit Fly Research and Development in Africa-Towards a Sustainable Management Strategy to Improve Horticulture; Springer International Publishing: Cham, Switzerland, 2016; ISBN 3-319-43226-5.

17. Ekesi, S.; Billah, M.K. A Field Guide to the Management of Economically Important Tephritid Fruit Flies in Africa, 2nd ed.; ICIPE Science Press: Nairobi, Kenya, 2007; ISBN 929064209.

18. Midingoyi, S.G.; Kassie, M.; Muriithi, B.; Diiro, G.; Ekesi, S. Do Farmers and the Environment Benefit from Adopting Integrated Pest Management Practices? Evidence from Kenya. J. Agric. Econ. 2019, 70, 452-470. [CrossRef]

19. Nyang'au, P.; Muriithi, B.; Nzuma, J.; Irungu, P.; Gichungi, H.; Diiro, G. Impact of integrated fruit fly management strategy on food security among smallholder mango farmers in Kenya. Afr. J. Food Agric. Nutr. Dev. 2020, 20, 15431-15454.

20. Genius, M.; Pantzios, C.J.; Tzouvelekas, V. Information acquisition and adoption of organic farming practices. J. Agric. Resour. Econ. 2006, 31, 93-113.

21. Jatoe, J.; Al-Hassan, R.; Abatania, L. Factors Affecting the Adoption of Improved Sorghum Varieties Among Farm Households in Northwest Ghana: A Probit Analysis. Ghana J. Dev. Stud. 2005, 2, 37-50.

22. An, H. The disadoption of rbST and its economic impact: A switching regression approach. Appl. Econ. Perspect. Policy 2013, 35, 528-549. [CrossRef]

23. Seid, H. Disadoption, Substitutability, and Complementarity of Agricultural Technologies; Discussion Paper Series, EfD DP 15-26; Environment for Development Initiative: Gothenburg, Sweden, 2015.

24. Neill, S.P.; Lee, D.R. Explaining the adoption and disadoption of sustainable agriculture: The case of cover crops in northern Honduras. Econ. Dev. Cult. Chang. 2001, 49, 793-820. [CrossRef]

25. Simtowe, F.; Mausch, K. Who is quitting? An analysis of the dis-adoption of climate smart sorghum varieties in Tanzania. Int. J. Clim. Chang. Strat. Manag. 2019, 11, 341-357. [CrossRef]

26. Kassie, M.; Shiferaw, B.; Muricho, G. Agricultural technology, crop income, and poverty alleviation in Uganda. World Dev. 2011, 39, 1784-1795. [CrossRef]

27. Shiferaw, B.; Kassie, M.; Jaleta, M.; Yirga, C. Adoption of improved wheat varieties and impacts on household food security in Ethiopia. Food Policy 2014, 44, 272-284. [CrossRef]

28. Moser, C.M.; Barrett, C.B. The disappointing adoption dynamics of a yield-increasing, low external-input technology: The case of SRI in Madagascar. Agri. Syst. 2003, 76, 1085-1100. [CrossRef]

29. Mudombi, G. Factors Affecting Perceptions and Responsiveness to Climate Variability Induced Hazards (No. 634-201641532). 2011. Available online: https://www.semanticscholar.org/paper/Factors-Affecting-Perceptions-and-Responsivenessto-Mudombi/a8a605d1636bf9c4a66f88db37d9978fc41494f1\#citing-papers (accessed on 25 March 2020).

30. Starkweather, J.; Moske, A.K. Multinomial Logistic Regression. 2011. Available online: http://www.unt.edu/rss/class/Jon/ Benchmarks/MLR_JDS_Aug2011.pdf (accessed on 27 March 2020).

31. Greene, W.H. Econometric Analysis, 5th ed.; Prentice-Hall: Upper Saddle River, NJ, USA, 2003.

32. Mwema, C.; Crewett, W. Social Networks, and Commercialisation of African Indigenous Vegetables in Kenya: A Cragg's Double Hurdle Approach. Cogent Econ. Financ. 2019, 7, 1642173. [CrossRef]

33. Prokopy, L.S.; Floress, K.; Klotthor-Weinkauf, D.; Baumgart-Getz, A. Determinants of agricultural best management practice adoption: Evidence from the literature. J. Soil Water Conserv. 2008, 63, 300-311. [CrossRef]

34. Allahyari, M.S.; Damalas, C.A.; Ebadattalab, M. Determinants of integrated pest management adoption for olive fruit fly (Bactrocera oleae) in Roudbar, Iran. Crop Prot. 2016, 84, 113-120. [CrossRef]

35. Balasha, A.M. Drivers of Adoption of Integrated Pest Management among Small-scale Vegetable Farmers in Lubumbashi, DR Congo. Am. J. Rural Dev. 2019, 7, 53-59.

36. Bonabana-Wabbi, J. Assessing Factors Affecting Adoption of Agricultural Technologies: The Case of Integrated Pest Management (IPM) in Kumi District, Eastern Uganda. Ph.D. Thesis, Virginia Polytechnic Institute and State University, Blacksburg, VA, USA, 2002.

37. Borkhani, F.R.; Rezvanfar, A.; Fami, H.S.; Pouratashi, M. Social factors influencing adoption of integrated pest management (IPM) technologies by paddy farmers. Int. J. Agric. Manag. Dev. Ijamad 2013, 3, 211-218.

38. Pannell, D.J.; Marshall, G.R.; Barr, N.; Curtis, A.; Vanclay, F.; Wilkinson, R. Understanding and promoting adoption of conservation practices by rural landholders. Aust. J. Exp. Agric. 2006, 46, 1407-1424. [CrossRef]

39. Neguse, T.B.; Wanzala, F.K.; Ali, W.M.; Owino, W.O.; Mwangi, G.S. Mango (Mangifera indica L.) production practices and constraints in major production regions of Ethiopia. Afr. J. Agric. Res. 2019, 14, 185-196. 
40. Van Melle, C.; Buschmann, S. Comparative analysis of mango value chain models in Benin, Burkina Faso and Ghana. In Rebuilding West Africa's Food Potential; FAO/IFAD: Rome, Italy, 2013.

41. Ddamulira, G.; Ramathani, I.; Sebikejje, T.; Naluyimba, R.; Otim, A.; Pariyo, A.; Maphosa, M. Mango Yield Performance in Lake Victoria Cresent Region of Uganda. Am. J. Plant Sci. 2019, 10, 1141. [CrossRef]

42. Government of Kenya Embu County Government. County Government Press. 2019. Available online: https://www.embu.go. ke/agriculture-livestock-fisheries-cooperative-development/ (accessed on 9 March 2019).

43. Parsa, S.; Morse, S.; Bonifacio, A.; Chancellor, T.C.; Condori, B.; Crespo-Pérez, V.; Hobbs, S.L.; Kroschel, J.; Ba, M.N.; Rebaudo, F. Obstacles to Integrated Pest Management Adoption in Developing Countries. Proc. Natl. Acad. Sci. USA 2014, 111, 3889-3894. [CrossRef]

44. Tsan, M.; Totapally, S.; Hailu, M.; Addom, B.K. The Digitalisation of African Agriculture Report 2018-2019; The Technical Centre for Agricultural and Rural Cooperation: Wageningen, The Netherlands, 2019. Available online: https://cgspace.cgiar.org/bitstream/ handle/10568/103198/Executive\%20Summary\%20V4.5\%20ONLINE.pdf (accessed on 10 May 2020).

45. Billah, M.; Mansell, M.W.; De Meyer, M.; Goergen, G. A Field Guide to the Management of Economically Important Tephritid Fruit Flies in Africa. In Fruit Fly Taxonomy and Identification; Ekesi, S., Billah, M.K., Eds.; ICIPE Science Press: Nairobi, Kenya, 2009; pp. H1-H19.

46. ISPM 26 (International Standards for Phytosanitary Measures). Establishment of Pest-Free Areas for Fruit Flies (Tephritidae); IPPC, FAO: Rome, Italy, 2006.

47. Mari, J.M.; Chachar, Q.I.; Chachar, S.D. Organic management of fruit fly in jujube ecosystem. Int. J. Agric. Technol. 2013, 9, 125-133.

48. Ekesi, S.; Tanga, C.M. Waste brewer's yeast as an alternative source of protein for use as a bait in the management of tephritid fruit flies. In Fruit Fly Research and Development in Africa-Towards a Sustainable Management Strategy to Improve Horticulture; Springer: Cham, Switzerland, 2016; pp. 293-306.

49. Reddy, K.D.; Anitha, V. Status of Insecticide Resistance in Oriental Fruit Fly Bactrocera dorsalis (Hendel) and Its Management. 2011. Available online: https://www.researchgate.net/profile/Vodur_Anitha/publication/325415550_Status_of_Insecticide_ resistance_in_Oriental_fruit_fly_and_its_management/links/5b0ceed4aca2725783ec5fe0/Status-of-Insecticide-resistance-inOriental-fruit-fly-and-its-management.pdf. (accessed on 12 August 2020).

50. Erbaugh, J.M.; Donnermeyer, J.; Amujal, M.; Kyamanywa, S. The role of women in pest management decision making in Eastern Uganda. J. Int. Agric. Ext. Educ. 2003, 10,71-81. [CrossRef]

51. Quisumbing, A.R.; Pandolfelli, L. Promising approaches to address the needs of poor female farmers: Resources, constraints, and interventions. World Dev. 2010, 38, 581-592. [CrossRef]

52. Kassie, M.; Stage, J.; Diiro, G.; Muriithi, B.; Muricho, G.; Ledermann, S.T.; Pittchar, J.; Midega, C.; Khan, Z. Push-pull farming system in Kenya: Implications for economic and social welfare. Land Use Policy 2018, 77, 186-198. [CrossRef]

53. Rivera, W.M.; Qamar, M.K. A New Extension Vision for Food Security—Challenge to Change; FAO: Rome, Italy, 2003.

54. Vanclay, F. Social principles for agricultural extension in facilitating the adoption of new practices. In Changing Land Management: Adoption of New Practices by Rural Landholders; Pannell, D., Vanclay, F., Eds.; CSIRO Publishing: Collingwood, Australia, 2011; pp. 51-67.

55. Poncet, J.; Kuper, M.; Chiche, J. Wandering off the paths of planned innovation: The role of formal and informal intermediaries in a large-scale irrigation scheme in Morocco. Agri. Sys. 2010, 103, 171-179. [CrossRef]

56. Muriithi, B.W.; Gathogo, N.G.; Diiro, G.M.; Mohamed, S.A.; Ekesi, S. Potential Adoption of Integrated Pest Management Strategy for Suppression of Mango Fruit Flies in East Africa: An Ex-Ante and Ex Post Analysis in Ethiopia and Kenya. Agriculture 2020, 10, 278. [CrossRef]

57. Sanglestsawai, S.; Rejesus, R.M.; Yorobe, J.M., Jr. Economic impacts of integrated pest management (IPM) farmer field schools (FFS): Evidence from onion farmers in the Philippines. Agric. Econ. 2015, 46, 149-162. [CrossRef]

58. Wambugu, C.; Place, F.; Franzel, S. Research, development and scaling-up the adoption of fodder shrub innovations in East Africa. Int. J. Agric. Sustain. 2011, 9, 100-109. [CrossRef]

59. Ajayi, O.C.; Place, F.; Akinnifesi, F.K.; Sileshi, G.W. Agricultural success from Africa: The case of fertilizer tree systems in southern Africa (Malawi, Tanzania, Mozambique, Zambia and Zimbabwe). Int. J. Agric. Sustain. 2011, 9, 129-136. [CrossRef]

60. Zwane, E.M. Does extension have a role to play in rural development? S. Afr. J. Agric. Ext. 2012, 40, 16-24.

61. Marenya, P.P.; Barrett, C.B. Household-level determinants of adoption of improved natural resources management practices among smallholder farmers in western Kenya. Food Policy 2007, 32, 515-536. [CrossRef]

62. Mugi-Ngenga, E.W.; Mucheru-Muna, M.W.; Mugwe, J.N.; Ngetich, F.K.; Mairura, F.S.; Mugendi, D.N. Household's socioeconomic factors influencing the level of adaptation to climate variability in the dry zones of Eastern Kenya. J. Rural Stud. 2016, 43, 49-60. [CrossRef]

63. Kabir, M.H.; Rainis, R. Adoption and intensity of integrated pest management (IPM) vegetable farming in Bangladesh: An approach to sustainable agricultural development. Env. Dev. Sustain. 2015, 17, 1413-1429. [CrossRef]

64. Talukder, A.; Sakib, M.; Islam, M. Determination of influencing factors for integrated pest management adoption: A logistic regression analysis. Agrotechnology 2017, 6, 2.

65. Mignouna, D.; Manyong, V.; Mutabazi, K.; Senkondo, E. Determinants of adopting imazapyr-resistant maize for Striga control in Western Kenya: A double-hurdle approach. J. Dev. Agric. Econ. 2011, 3, 572-580. 